\title{
An Experimental Study on the Dermal Effect of Skincare Apparatuses for Home Use
}

\author{
Byung-wook Chin \\ Faculty of Convergence \& Integration, Hansung University, Seoul, Korea
}

Corresponding author: Byung-wook Chin, Faculty of Convergence \& Integration, Hansung University, 116 Samseongyo-ro 16 gil, Seongbuk-gu, Seoul 02864, Korea Tel.: +822 7605892

Fax: +82 27604442

Email: bwook@naver.com

Received July 6, 2020

Revised April 26, 2021

Accepted June 01, 2021

Published June 30, 2021

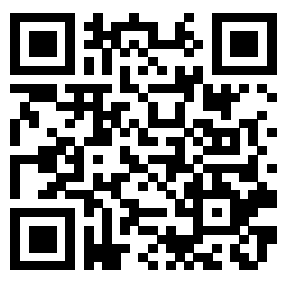

\begin{abstract}
Purpose: The purpose of this study is to reemphasize the validity of developing a small sized skin-care tool that is convenient to use in common households, and to objectively prove whether an at-home skin-care device with personal mobility can have the positive effects on skin (especially whitening effect) and psychological satisfaction. Methods: This study required the test subjects to use at least two functions including hypoallergenic peeling function and dead skin cell care for more than once a day. Afterward the changes in skin whitening was measured (changes in skin brightness and tone) and survey responses were collected. The study was conducted for 8 weeks' period, and the skin color and tone was measured twice, before and after the study. The survey was taken once in a form of 5 point Likert scale. Result: First, measuring changes in skin tone after the use of the product showed that in $66 \%$ in age group of 18 to 19 , and $83 \%$ in age group of over 20 , the product was effective. So, in total $79 \%$ experienced increase in brightness of the skin. Among the $29 \%$ of the subjects that showed decrease in skin tone using the toolkit, some admitted that there was an error during self-measurement process, and some expressed that with naked eyes the skin appears to be brighter after using the product. This may be due to changes in colors of the skin that was not part of the measurement. Secondly, in the survey assessing the psychological satisfaction from using the product, test subjects gave $79 \%$ to $100 \%$ positive responses. Conclusion: The study confirmed that an at-home skin-care device has a positive effect on the user's skin beauty (especially whitening effect) and psychological satisfaction of the user.
\end{abstract}

Keywords: Home care, Self-face care, Galvanic, Mask pack care, Portable face-care

\section{Introduction}

최근, 건강과 미에 대한 향상과 미적인 요구는 더욱 전문화, 고급 화, 차별화를 요구하고 있으며 이러한 시대적 변화에 발 맞추어 국 내에도 많은 관심과 성장을 가져왔다(Jung \& Kim, 2010). 특히 사 회 각 분야에서 활약하는 전문직 여성계층의 확대와 여성소득의 증 가, 그리고 이로 인해 파생되는 개인의 미에 대한 투자의 증가추세 는 결과적으로 피부미용 시장의 확산을 가져오고 있다(Kim, 2007). 일반적으로 상대의 외모를 통해 그의 내면과 인성을 평가하려는 경 향으로 인해, 외모가 대인관계에 영향을 미치는 시대로 접어들었다 (Yun \& Kim, 2018). 아울러 고령화 및 삶의 질 향상 등 지역사회의 변화에 따른 수요증가 및 관련산업의 기술발전 등의 영향에 의해, 피
부미용산업의 시장이 변화하고 있다. 지역별 시장규모의 변화를 보 면, 2014년 북미(45.1\%), 유럽(21.7\%), 아시아-태평양(17.5\%)의 순 이었으나, 최근에는 아시아-태평양 시장이 연평균 $15.7 \%$ 의 높은 성 장률을 기록하는 한편, 유럽 시장은 상대적으로 낮은 $8.8 \%$ 의 연평균 성장률을 기록하고 있다. 국내시장의 경우도, 최근 전국의 미용관련 병·의원이 크게 증가하면서 관련시장을 견인하고 있어서, 2014년 3,852 억원에서 2020 년 1 조 1,316 억 원으로 연평균 $19.7 \%$ 성장을 하고 있는 추세이다. 미용기기 시장의 주요 특징으로 미국, 유럽 등 선진국의 경우 안티에이징 관련 시장이 $40 \%$ 이상을 차지하는 반면, 아시아의 경우 $20 \%$ 수준이며, 동남아 지역의 경우 미백관련 수요가 상대적으로 높다. 아울러 시장의 주요 트렌드는 시술비용과 회복기 간 및 부작용의 최소화를 위한 비침습 또는 최소 침습형 기기를 선호 
하는 경향이며, 다기능화 및 DIY 수요에 따른 가정용 미용기기에 대 한 요구가 증가하는 경향이다(Park \& Choi, 2019). 대부분의 피부미 용기기의 사용은 여성이 주된 고객이며 이로 인하여 그 개발은 주로 여성의 요구(needs)에서 출발하게 된다. 특히 사회 각 분야에서 활약 하는 전문직 여성계층의 확대와 여성소득의 증가, 그리고 이로 인해 파생되는 개인의 미에 대한 투자가 증가하고 있는 실정이며 결과적 으로 피부미용시장의 확산을 가져오고 있다(Kim et al, , 2007). 최근 에는 여성적 행위로만 간주되어 왔던 외모관리에 대한 남성들의 태 도가 변화되고 있으며, 남성 글루밍(glooming)족 이라 불리우는 이 들은 외모에 투자하고 심지어 먹고 마시는 것 까지도 건강과 영양 을 고려해 꼼꼼히 선택하는 헬시(healthy)족이 증가하고 있다(Park $\&$ Lee, 2019). 또한 노년층에 있어서도 외모의 중요성이 개인적, 사 회적으로 다양한 영역에서 장점으로 영향력을 발휘하고 있다(Kim, 2019).

한편, 가정용 피부미용기기의 경우 합리적 소비를 추구하는 문 화가 정착되며 피부과나 피부관리실에서 시간과 비용을 들여 관리 를 받던 소비자가 홈뷰티에 관심을 쏟고 있어서 전 세계적으로 가정 용 미용기기의 시장규모가 꾸준히 성장하고 있는 가운데, 글로벌 시 장규모는 2017년 30조원에서 2022년 40조원의 시장으로 연평균 $7.6 \%$ 의 성장세가 예상되고 있어, 이는 글로벌 화장품 시장의 연평균 성장률 5.3\%보다 상대적으로 높게 나타나고 있다. 가정용 피부미용 기기의 경우 초기에는 주로 구조가 간단한 경피 약물전달 기기가 주 류였으나, 2010년 이후부터는 다양한 병•의원용 미용 의료기기와 같은 원리가 적용된 약물전달 보조기기, 레이저, 고주파, $\mathrm{LED}$ 뿐만 아니라 원적외선, 초음파, 갈바닉 이온 등을 활용한 소형화가 비교적 용이한 기술군 위주의 다양한 제품들이 대거 출시되고 있다(Park \& Choi, 2019). 이에 따라 이번 연구를 통하여 일반 가정에서 쉽게 사 용할 수 있는 소형 피부미용기기 개발의 타당성을 제고함은 물론, 퍼 스널 모빌리티성을 강조한 가정용 피부미용기기가 사용자의 피부미 용(특히 미백효과)에 미치는 긍정적인 효과와 심리적인 만족감을 충 실히 높여 줄 수 있는 지에 대하여 객관적으로 입증하는 것이 이 연 구의 목적이다.

\section{Methods}

\section{1. 연구대상}

본 연구를 위한 임상실험은 2020년 4월부터 6 월까지 서울 및 수 도권에 거주하는 만 18 세 이상의 성인남녀 33 명을 대상으로 이루어 겼으며 실험 참여자들은 해당 임상실험에 대한 설명을 들은 후, 개인 정보사용 및 실험 및 연구과정 참가에 동의한 사람들을 대상으로 선 발하였다.

\section{2. 연구방법}

본 연구는 갈바닉 이온을 발생시키는 피부 케어 제품 클렌슈어 프 로페셔널 샤이닝 시스템 UP(아이젤크리에이티브, Korea)을 사용하 여, 저자극 필링 기능과, 각질케어 기능의 2가지 케어기능을 피 실험 자 스스로가 1 일 1 회이상, 실시 후, 피부미백(피부밝기 및 톤 변화) 에 대한 측정 및 설문지를 작성하도록 하였다. 총 실험기간은 8주에 걸쳐 실시 되었으며, 피부 색상 및 피부 톤 검사는 실험 전과 후로 2 회의 측정을 실시하였고, 설문지는 전체 실험 실시 후 1 회, 5 점척도 평가의 설문방식으로 실시하였다.

\section{3. 사용제품 및 측정용 툴킷}

1) 임상실험을 위한 제품

이번 연구 실험을 위한 제품으로는 소형 가정용 피부 클렌슈어 샤 이닝 시스템 UP 제품(아이젤크리에이티브)으로 초당 3 만번의 저자 극 초음파 주사기능과, 신체에 흐르는 미세한 전류를 활용한 음이온 (갈바닉)마사지 기능을 보유하고 있다.

\section{2) 피부색 및 톤 측정용 툴킷}

피부색 측색기 스마트 CUBE (Palette, Australia)제품은 육안측 정의 주관성을 극복하고, 통계에 의한 체계적인 퍼스널컬러의 측색 과 분석이 가능한 도구로서 스마트폰의 전용 앱과 연동하여 사용하 는 제품이다.

3) 피부색 및 톤 값 산출

본 연구 및 실험을 위한 피부 톤 측정 및 변화의 값을 산출하기 위하여 (주)코코리색채연구소가 제공하는 PCS 퍼스널컬러시스템의

Table 1. General characteristics of the subjects

\begin{tabular}{lcc}
\hline General characteristic & Classification & $N(\%)$ \\
Gender & Male & $10(30.3)$ \\
& Female & $23(69.7)$ \\
Age (years) & $\leq 18(\mathrm{~A})$ & $3(9.1)$ \\
& $19(\mathrm{~B})$ & $6(18.2)$ \\
Total & $\geq 20(\mathrm{C})$ & $24(72.7)$ \\
\hline
\end{tabular}


tone 값 측정 방법 및 산출공식을 활용하였으며, 각 항목별 세부기준

은 다음과 같다.

i. 측정값(LAB값) 읽기

$\mathrm{L}^{*}=$ 밝기(black/0-white/100)

$\mathrm{a}^{*}=$ 채도(red/100-green/-100)

$\mathrm{b}^{*}=$ 채도(yellow/100-blue/-100)

ii. $L^{*}$ 값의 기준

75 이상=창백함

66이상=하얀 피부
63-65=한국인의 중간밝기

60-62=건강한 밝기

60 이하=거무잡잡함

iii. $a^{*}$ 값의 기준

$13-15=$ 한국인의 평균값

iv. $b$ 값의 기준

$19-21=$ 한국인의 평균값

v. 변화량 $(\Delta \mathrm{E} a b)=\sqrt{ }(\mathrm{L} 1-\mathrm{L} 2)^{2}+(\mathrm{a} 1-\mathrm{a} 2)^{2}+(\mathrm{b} 1-\mathrm{b} 2)^{2}$

Table 2. Results of color and tone measurements by group

\begin{tabular}{|c|c|c|c|}
\hline User & $\begin{array}{c}\text { Before test } \\
L^{*} / a^{*} / b^{*}\end{array}$ & $\begin{array}{l}\text { After test } \\
\mathrm{L}^{*} / \mathrm{a}^{*} / \mathrm{b}^{*}\end{array}$ & $\Delta \mathrm{E}$ \\
\hline$A-1$ & $60.1 / 15.2 / 41.7$ & $57.8 / 19.7 / 22.0$ & 20.3 \\
\hline$A-2$ & $54.8 / 18.3 / 23.4$ & $61.6 / 14.3 / 19.4$ & 8.9 \\
\hline$A-3$ & $57.4 / 17.3 / 22.5$ & $58.4 / 16.7 / 19.6$ & 3.1 \\
\hline B-1 & 59.0/17.3/19.9 & $64.4 / 14.2 / 18.5$ & 6.4 \\
\hline B-2 & 58.3/21.3/16.9 & $57.3 / 20.0 / 19.8$ & 3.4 \\
\hline B-3 & $52.4 / 18.6 / 23.9$ & $56.3 / 17.5 / 22.4$ & 4.3 \\
\hline B-4 & $57.3 / 18.0 / 22.0$ & $63.5 / 13.7 / 18.7$ & 8.3 \\
\hline B-5 & $56.7 / 17.0 / 22.4$ & $60.8 / 16.0 / 19.7$ & 4.9 \\
\hline B-6 & $61.0 / 15.5 / 21.0$ & $60.8 / 16.2 / 20.9$ & 0.8 \\
\hline C-1 & $58.8 / 16.2 / 22.3$ & $65.0 / 14.4 / 18.9$ & 7.3 \\
\hline $\mathrm{C}-2$ & $57.8 / 17.9 / 21.1$ & $65.1 / 13.7 / 16.8$ & 8.7 \\
\hline C-3 & $58.9 / 16.1 / 21.0$ & $62.1 / 14.9 / 23.0$ & 4.0 \\
\hline C-4 & $58.2 / 16.9 / 23.0$ & $60.1 / 15.4 / 23.3$ & 2.5 \\
\hline$C-5$ & $58.6 / 16.0 / 22.6$ & $61.1 / 16.7 / 19.8$ & 3.8 \\
\hline C-6 & $60.1 / 16.9 / 21.2$ & $65.0 / 13.2 / 20.6$ & 6.1 \\
\hline $\mathrm{C}-7$ & $56.8 / 17.8 / 22.3$ & $60.5 / 15.5 / 19.9$ & 5.0 \\
\hline $\mathrm{C}-8$ & $55.6 / 18.8 / 20.4$ & $60.9 / 14.0 / 23.8$ & 8.0 \\
\hline C-9 & $64.8 / 14.6 / 18.9$ & $61.3 / 15.8 / 18.0$ & 3.8 \\
\hline C-10 & $58.9 / 15.5 / 20.3$ & $62.2 / 13.9 / 21.2$ & 3.8 \\
\hline C-11 & $58.9 / 17.2 / 23.2$ & $61.7 / 15.2 / 20.8$ & 4.1 \\
\hline C-12 & $65.7 / 11.6 / 19.5$ & $64.4 / 12.3 / 20.2$ & 1.6 \\
\hline C-13 & $65.5 / 12.8 / 19.4$ & $63.9 / 12.2 / 21.6$ & 2.8 \\
\hline C-14 & $63.3 / 12.2 / 16.0$ & $64.5 / 14.0 / 20.8$ & 5.2 \\
\hline C-15 & 61.1/18.0/19.2 & $59.9 / 19.1 / 19.5$ & 1.7 \\
\hline C-16 & 59.1/19.6/19.1 & $60.1 / 18.1 / 19.4$ & 1.8 \\
\hline $\mathrm{C}-17$ & $57.9 / 19.2 / 21.8$ & $60.6 / 17.6 / 19.2$ & 3.7 \\
\hline C-18 & $59.8 / 18.8 / 20.8$ & $64.8 / 15.3 / 15.4$ & 8.2 \\
\hline C-19 & $59.9 / 19.0 / 18.6$ & $67.1 / 14.2 / 15.3$ & 9.2 \\
\hline $\mathrm{C}-20$ & $58.8 / 19.1 / 19.5$ & $68.2 / 12.4 / 13.8$ & 12.9 \\
\hline C-21 & $59.1 / 18.8 / 20.3$ & $65.6 / 14.4 / 14.7$ & 9.6 \\
\hline $\mathrm{C}-22$ & $56.0 / 11.1 / 128$ & $66.5 / 12.6 / 15.1$ & 113.0 \\
\hline $\mathrm{C}-23$ & $58.7 / 19.8 / 19.6$ & $55.7 / 17.8 / 128$ & 108.0 \\
\hline $\mathrm{C}-24$ & $59.4 / 16.0 / 40.1$ & $61.1 / 13.7 / 18.1$ & 22.1 \\
\hline
\end{tabular}

A group, under 18 years old; B group, 19 years old; C group, 20 years old or above. 


\section{4. 피부 색상 및 피부 톤의 측정}

본 연구를 위하여 피 실험자에게 피부 클렌슈어 프로페셔널 샤 이닝 시스템 $\mathrm{UP}($ 아이젤크리에이티브) 제품의 저자극 필링 기능 과, 각질케어 2가지 기능을 각 5-10 $\mathrm{min}$ 씩 총 10-20 $\mathrm{min}$ 정도 를 8 주동안 매일 사용하게 하였다. 아울러 피부색 변화의 측정용 툴 킷 으로는 CUBE (Palette사, Australia)를 사용하여 국제조명위원 회(International Commission on Illumination, CIE)에서 지정한 CIELab값을 추출하고, 아울러 (주)코코리색채연구소(Korea)가 제공 한 한국인의 피부색 표준 tone의 범위와, 분류체계, 그리고 tone값
산출공식에 따라 수치를 산출하고 분석하였다.

스마트 CUBE 측색기를 사용한 피부측정은 피 실험자가 세안 후 민 낯 상태에서의 볼 부위(눈꼬리와 입꼬리가 교차하는 부위)를 특정하 여 평가실험을 시작하기 전과 8주간의 평가 실험을 종료한 후, 총 2회 를 통해 측정을 실시 하였으며, 한번 측정 시 3 회의 측정을 통하여 나 타난 평균값을 적용하였다. 본 연구에 활용한 피부 측정값은 Palette 사(Australia)가 제공하는 5 가지의 컬러데이터 표시형식 중에서 LAB 형식을 취하고, 이를 (주코코리색채연구소가 개발한 tone값 산출공식 에 대입하여 활용하였다. 아울러 피 실험자는 매일 일정시간에 실험

Table 3. Results of survey after product use experiment

\begin{tabular}{|c|c|c|c|}
\hline & & Frequency & $\%$ \\
\hline \multirow{5}{*}{ It seems to have the effect of whitening the skin } & A sure feeling & 17 & 52 \\
\hline & Very much so & 5 & 15 \\
\hline & Ordinary & 2 & 6 \\
\hline & A little & 2 & 6 \\
\hline & Not at all & 7 & 21 \\
\hline \multirow{5}{*}{ My skin seems to be less dry than before } & A sure feeling & 14 & 43 \\
\hline & Very much so & 8 & 24 \\
\hline & Ordinary & 4 & 12 \\
\hline & A little & 7 & 21 \\
\hline & Not at all & 0 & 0 \\
\hline \multirow{5}{*}{ My skin seems to have gotten cleaner } & A sure feeling & 15 & 46 \\
\hline & Very much so & 9 & 27 \\
\hline & Ordinary & 5 & 15 \\
\hline & A little & 4 & 12 \\
\hline & Not at all & 0 & 0 \\
\hline \multirow{5}{*}{ My skin seems to have gotten smooth } & A sure feeling & 16 & 49 \\
\hline & Very much so & 7 & 21 \\
\hline & Ordinary & 3 & 9 \\
\hline & A little & 7 & 21 \\
\hline & Not at all & 0 & 0 \\
\hline \multirow{5}{*}{ I think my skin color has improved } & A sure feeling & 18 & 55 \\
\hline & Very much so & 4 & 12 \\
\hline & Ordinary & 2 & 6 \\
\hline & A little & 2 & 6 \\
\hline & Not at all & 7 & 21 \\
\hline \multirow{5}{*}{ My skin seems to have gotten healthier } & A sure feeling & 17 & 52 \\
\hline & Very much so & 5 & 15 \\
\hline & Ordinary & 9 & 29 \\
\hline & A little & 2 & 6 \\
\hline & Not at all & 0 & 0 \\
\hline \multirow{5}{*}{ I feel refreshed } & A sure feeling & 19 & 58 \\
\hline & Very much so & 7 & 21 \\
\hline & Ordinary & 5 & 15 \\
\hline & A little & 2 & 6 \\
\hline & Not at all & 0 & 0 \\
\hline
\end{tabular}


용으로 지급된 클렌슈어 프로페셔널 샤이닝 시스템 UP(아이젤크리 에이티브)제품을 사용한 후, 자신의 피부상태를 촬영하여 영상기록을 하게 하였고, 아울러 피부색의 측정을 균일하게 하기 위한 조건으로 가급적 동일장소와 동일 시간대, 동일한 광원을 사용하여 관찰 및 촬 영을 하게 하였다.

\section{5. 설문조사}

설문조사는 피부 tone및 색상의 측정실험이 종료된 후 피 실험자 피부의 관능평가 및 기분상태의 평가를 위한 것으로 실험 결과에 대 한 일반적인 질문 4 개 문항 및 기분상태에 관한 총 7 개 문항으로 구 성되었으며, 기분상태 평가 문항은 1) 피부 미백의 효과가 있는 것 같 다; 2) 피부의 건조가 전보다 덜한 것 같다; 3) 피부가 깨끗해진 것 같 다; 4) 피부가 매끄러워 진 것 같다; 5) 피부색이 좋아 진 것 같다; 6 ) 피부가 건강해진 것 같다; 7) 상쾌한 기분이 든다 등에 대한 문항에 대하여 5점 척도 평가를 실시 하였다.

\section{6. 데이터 분석}

스마트 CUBE 측색기 및 연결 앱을 통해 나타나는 측정값의 비교 를 통해 피부의 밝기에 대한 변화 값을 평균, 표준편차, 빈도, 백분율 을 산출하여 분석하였다.

\section{Results and Discussion}

\section{1. 피 실험대상의 일반적 특성}

서울 및 수도권 지역에 거주하는 피 실험자 33 명의 일반적인 특성 으로는 Table 1 과 같이, 성별은 남자 $30 \%$, 여자 $70 \%$, 나이는 만 19 세 가 $18.2 \%$, 만 18 세 이하가 $9.1 \%$, 만 20 세 이상이 $72.7 \%$ 로 나타났다.

\section{2. 피부색상 및 톤 변화 측정 결과}

피 실험자를 연령별 3 개(A, B, C) 그룹으로 나누어 클렌슈어 제품 을 8주간 사용하게 하여 나타난 피부색과 피부 tone의 변화를 측정 용 툴킷(스마트'CUBE' 측색기 및 연결 앱)으로 측정하고, 이를 피 실 험자의 실험 전·후 측정결과 값 별로 비교를 실시, 추출된 $\mathrm{L}^{*}, \mathrm{a}^{*}, \mathrm{~b}^{*}$ 값과 $\Delta \mathrm{E}$ 값(변화량)은 Table 2과 같이 나타났다.

8 주간의 사용실험 후 피부톤을 측정한 결과, Table 2 에서 표기된 바와 같이 전체 피 실험자 33 명 중 $79 \%$ 인 26 명이 피부의 밝기가 밝 아진 것으로 나타났으며, 나머지 7명(A그룹 1명, B그룹 2 명, C그룹 4 명)은 실험 전보다 피부의 밝기가 오히려 어둡게 나타났는데, 이들 은 측정용 툴 킷으로 제공한 $\mathrm{CUBE}$ 와 연결 앱의 사용방법을 잘 이해 하지 못한 관계로 측정상의 오류가 원인으로 판명되었다. 특히 $\Delta \mathrm{E}$ 값이 5 이상으로 육안으로 구별 될 만큼 확실한 변화를 보인 비율이 전체의 $45 \%$ 로 나타나 본 연구실험에 사용된 클렌슈어 제품의 피부 미백에 대한 효과를 증명할 수 있게 되었다. 각 그룹별로 분석 해 보
면, A그륩과 B그륩에 있어서, $66 \%$ 가 효과를 나타낸 반면, $33 \%$ 가 비 효과적이었고, $\mathrm{C}$ 그룹에 있어서는 $83 \%$ 가 효과를 나타낸 반면 $17 \%$ 가 비 효과적으로 나타나게 되어, C그룹인 20세 이상의 피 실험자 그룹 에서 피부 톤 변화에 대한 효과가 가장 크게 나타난 것을 알 수 있다.

\section{3. 설문조사 결과}

실험 후 만족도에 대한 설문조사 결과는 Table 3 와 같이 나타났 다. 먼저, '피부미백의 효과가 확실히 있는 것 같다'는 피 실험자가 $52 \%$, '약간이라도 그런 것 같다' 이상의 피실험자가 $79 \%$ 로 응답하였 고, '피부색이 약간이라도 좋아진 것 같다'는 피 실험자가 $79 \%$ 이상 으로 응답하였으며, '피부가 약간이라도 깨끗해 진 것 같다'의 응답 이 $100 \%$ 로 응답하여, 제품 사용 후 피부 미백 효과에 대한 만족도가 매우 높은 것으로 응답 하였다. 다음으로, '피부의 건조가 덜 해진 것 같다'의 응답이 $100 \%$, '피부가 매끄러워 진 것 같다'의 응답이 $100 \%$, '피부가 건강 해 진 같다'의 응답이 $100 \%$, '제품 사용 후 상쾌한 기분 이 든다' 라고 응답한 피 실험자가 $100 \%$ 로 나타나, 본 실험에 참가한 대부분의 피 실험자가 감성적으로도 제품의 사용결과에 만족하고 있 음을 나타내고 있다.

\section{Conclusion}

이상의 제품 임상실험 연구를 통하여 프로페셔널 샤이닝 시스템 UP 제품이 사용자의 피부미용(특히 미백효과)에 미치는 긍정적인 효 과가 있다는 것을 알게 되었고 아울러, 제품 사용자의 심리적인 만족 감을 충실히 높여 줄 수 있다는 것을 알게 되었으며, 세부적인 연구 결과는 다음과 같다.

첫째, 제품 사용 후 피부 톤 변화에 대한 측정 결과, 18 세-19세의 그룹에서는 $66 \%, 20$ 세 이상의 그룹에서는 $83 \%$ 의 효과를 나타내어 전체 피 실험자 가운데 $79 \%$ 의 피부가 밝아진 것으로 나타났다.

그러나, 피부 톤 측정 툴킷으로 측정을 했을 때 오히려 어둡게 나 타난 $29 \%$ 의 피 실험자 집단에서도 스스로 측정 오류를 인정하거나, 자신들의 시각적 느낌으로는 오히려 밝아 보인다고 하는 경우가 있 었다.

이는 아마도 이번 연구 실험에서는 세부적으로 비교를 하지 않은 색상의 변화가 개인들의 시각적 효과에 지대한 영향을 주었을 것으 로 판단된다.

둘째, 제품 사용후의 심리적 만족감에 대한 조사결과, 피부미백 과 직접 관련이 있는 문항에 대하여 79-100\%까지의 긍정적인 응답 을 하였다. 이 또한 위에서 언급한 피부 밝기의 변화 외에, 색상의 변 화가 더욱 크게 작용을 하는 것으로 판단되어, 차후의 동일한 연구에 있어서는 LAB 표시형식에 있어서, 색상의 변화에 대해서도 함께 비 교 분석한다면 더욱 구체적인 결론을 도출 할 수 있을 것으로 본다. 


\section{Acknowledgements}

This research was financially supported by Hansung University.

\section{Author's contribution}

BWC is an independent researcher for the study. BWC designed questionnaire, analyzed data, and wrote manuscript.

\section{Author details}

Byung-wook Chin (Professor), Faculty of Convergence \& Integration, Hansung University, 116 Samseongyo-ro 16 gil, Seongbuk-gu, Seoul 02864, Korea.

\section{References}

Jung BY, Kim EH. Study on the use of skin beauty appliances in skin beauty rooms. Asian Journal of Beauty and Cosmetology, 8: 155-164, 2010.

Kim EK. Personal image types and preference analysis of male celebrities in the silver generation. Asian Journal of Beauty and Cosmetology, 17: 467-476, 2019.

Kim GY, Kim EJ, Yeon JA, Park YE. A comparative study of skin clinic experiment and feeling state before and after using nano-cold steam skin care machine. Asian Journal of Beauty and Cosmetology, 5: 199-208, 2007.

Kim KY. Die entwicklung des nanokaltdampfgeraets und dessen anwendung auf die haut. Asian Journal of Beauty and Cosmetology, 5: 35-46, 2007.

Park JH, Choi YS. Beauty and medical device technology trends and industry prospects. KEIT PD Issue Report, 7: 18-28, 2019.

Park JY, Lee MS. Influence of beauty care on well-beingoriented behaviors and well-aging behaviors in adult men. Asian Journal of Beauty and Cosmetology, 17: 93-106, 2019.

Yun HS, Kim HJ. A clinical experimental study on tooth whitening effectiveness in toothpaste of containing natural extracts. Journal of the Korean Society of Dental Hygiene, 18: 19-29, 2018. 
국문초록

\section{홈 케어 피부미용기기의 피부임상실험 연구}

진병욱

한성대학교 자율교양대학, 서울, 한국

목적: 본 연구는 퍼스널 모빌리티성을 강조한 가정용 피부미용기기가 사용자의 피부미용(특히 미백효과)에 미치는 긍정적인 효과와 심리적인 만족감을 충실히 높여 줄 수 있는 지에 대하여 객관적으로 입증하고자 한다. 방법: 본 연구는 저자극 필링기능과, 각질케 어 기능의 2 가지 기능을 피 실험자 스스로가 1 일 1 회이상, 실시 후, 피부미백(피부밝기 및 톤 변화)에 대한 측정 및 설문지를 작성하 도록 하였다. 총 실험기간은 8 주에 걸쳐 실시 되었으며, 설문지는 전체 실험 실시 후 1 회, 5 점 척도 평가의 설문방식으로 실시하였 다. 결과: 첫째, 제품 사용 후 피부 톤 변화에 대한 측정 결과, 18 세-19세의 그룹에서는 $66 \%, 20$ 세 이상의 그룹에서는 $83 \%$ 의 효과 를 나타내어 전체 피 실험자 가운데 $79 \%$ 의 피부가 밝아진 것으로 나타났다. 그러나, 피부 톤 측정 툴킷으로 측정을 했을 때 오히려 어둡게 나타난 $29 \%$ 의 피 실험자 집단에서도 스스로 측정 오류를 인정하거나, 자신들의 시각적 느낌으로는 오히려 밝아 보인다고 하는 경우가 있었다. 이는 아마도 이번 연구. 실험에서는 세부적으로 비교를 하지 않은 색상의 변화가 개인들의 시각적 효과에 지대 한 영향을 주었을 것으로 판단된다. 둘째, 제품 사용후의 심리적 만족감에 대한 조사결과, 피부미백과 직접 관련이 있는 문항에 대 하여 79\%-100\%까지의 긍정적인 응답을 하였다. 결론: 본 연구를 통하여 프로페셔널 샤이닝 시스템 UP 제품이 사용자의 피부미용 (특히 미백효과)에 긍정적인 효과가 있다는 것을 알게 되었고 아울러, 제품 사용자의 심리적인 만족감을 충실히 높여 줄 수 있다는 것을 알게 되었다.

핵심어: 홈케어 미용, 셀프미용, 갈바닉, 마스크팩 케어, 휴대용 페이스케어

This research was financially supported by Hansung University.

\section{참고문헌}

김기연, 김은자, 연정아, 박영은. 나노콜드스팀 피부미용기기 사용 전·후 피부임상실험의 감성 비교연구. 아시안뷰티화장 품학술지, 5: 199-208, 2007.

김기연. 기능성 나노콜드스팀 피부미용기기 개발과 그 응용제품의 피부임상실험 연구. 아시안뷰티화장품학술지, $5: 35-$ 46, 2007.

김애경. 실버세대 남자 유명인의 퍼스널 이미지 유형화 및 선호도 분석. 아시안뷰티화장품학술지, 17: 467-476, 2019. 박재영, 이명선. 성인 남성의 미용관리가 웰빙지향 행동과 웰에이징 행위에 미치는 영향. 아시안뷰티화장품학술지, 17 : 93-106, 2019.

박지훈, 최연식. 미용의료기기 기술동향과 산업전망. KEIT PD Issue Report, 7: 18-28, 2019.

윤현서, 김혜진. 천연추출물은 함유한 세치제의 치아미백효능에 대한 임상적 실험 연구. 한국치위생학회지, 18: 19-29, 2018.

정보연, 김은화. 피부미용실에서의 피부미용기기 사용 실태 연구. 아시안뷰티화장품학술지, 8: 155-164, 2010. 


\section{中文摘要}

\section{家用护理护肤仪的皮肤临床试验研究}

陳炳旭

汉城大学自律教养大学, 首尔, 韩国

目的: 本研究的目的是再次强调开发一种便于普通家庭使用的小型护肤工具的有效性, 并客观证明具有个人移动 性的家用护肤设备对皮肤的影响（尤其是美白效果）和心理满足感是否具有积极意义。方法: 这项研究要求测试 对象每天至少使用两个功能, 即低过敏性去角质功能和死皮细胞护理。然后测量皮肤美白的变化（皮肤亮度和 色调的变化）并收集调查响应。该研究进行了8周, 并在研究之前和之后测量了皮肤颜色和色调两次。该调查以 5点量表评估的形式进行一次。结果：首先，测量使用该产品后的肤色变化表明，该产品在 18至19岁年龄段的 $66 \%$ 和 20 岁以上年龄段的 $83 \%$ 中有效。因此, 总共有 $79 \%$ 的人经历了皮肤亮度的增加。在 $29 \%$ 使用工具包出现 肤色下降的受试者中, 有的承认自我测量过程中存在错误, 有的表示使用该产品后, 用肉眼观察皮肤似乎更亮 了。这可能是由于皮肤颜色的变化不是测量的一部分。其次，在评估使用产品的心理满意度的调查中，测试对 象给出了 79\%到100\%的积极响应。结论: 研究证实, 家用护肤仪对用户的皮肤美容（尤其是美白效果）和用户 心理满意度有积极影响。

关键词: 家庭护理, 自我面部护理, 电镀, 面膜护理, 便携式面部护理 